\title{
The Crabb Site (41TT650), a Prehistoric Caddo Site on Tankersley Creek, Titus County, Texas
}

Bo Nelson

Heritage Research Center, Stephen F. Austin State University

Marty Crabb

Timothy K. Perttula

Heritage Research Center, Stephen F. Austin State University

LeeAnnaa Schniebs

Follow this and additional works at: https://scholarworks.sfasu.edu/ita

Part of the American Material Culture Commons, Archaeological Anthropology Commons, Environmental Studies Commons, Other American Studies Commons, Other Arts and Humanities Commons, Other History of Art, Architecture, and Archaeology Commons, and the United States History Commons

Tell us how this article helped you.

This Article is brought to you for free and open access by the Center for Regional Heritage Research at SFA ScholarWorks. It has been accepted for inclusion in Index of Texas Archaeology: Open Access Gray Literature from the Lone Star State by an authorized editor of SFA ScholarWorks. For more information, please contact cdsscholarworks@sfasu.edu. 


\section{The Crabb Site (41TT650), a Prehistoric Caddo Site on Tankersley Creek, Titus County, Texas}

\section{Creative Commons License}

\section{(c) (1) \&}

This work is licensed under a Creative Commons Attribution-NonCommercial 4.0 International License 


\title{
The Crabb Site (41TT650), a Prehistoric Caddo Site on Tankersley Creek, Titus County, Texas
}

\author{
Bo Nelson, Marty Crabb, and Timothy K. Perttula \\ with a contribution by LeeAnna Schniebs
}

\section{INTRODUCTION}

In this article, we discuss the archaeological findings at the Crabb site (41TT650), a prehistoric Caddo settlement on an upland remnant/knoll in the Tankersley Creek floodplain in Titus County, Texas (Figure 1). Tankerslcy Creek is one of the principal tributaries of Big Cypress Creek, and it flows south past the Crabb site to merge with the larger creek a few miles downstream. This part of Titus County is in the Pineywoods, an area with abundant moisture and a warm, moderate climate in modern times, with an overstory vegetation of pines and a variety of hardwoods (principally several species of oaks and hickory). Along Tankersley Creek itself, the vegetation would have been dominated by more mesic hardwoods that tolerated occasional inundation from seasonal floods and standing water in the floodplain, such as water oaks and sweetgum trees, bushes, vines, and shrubs.

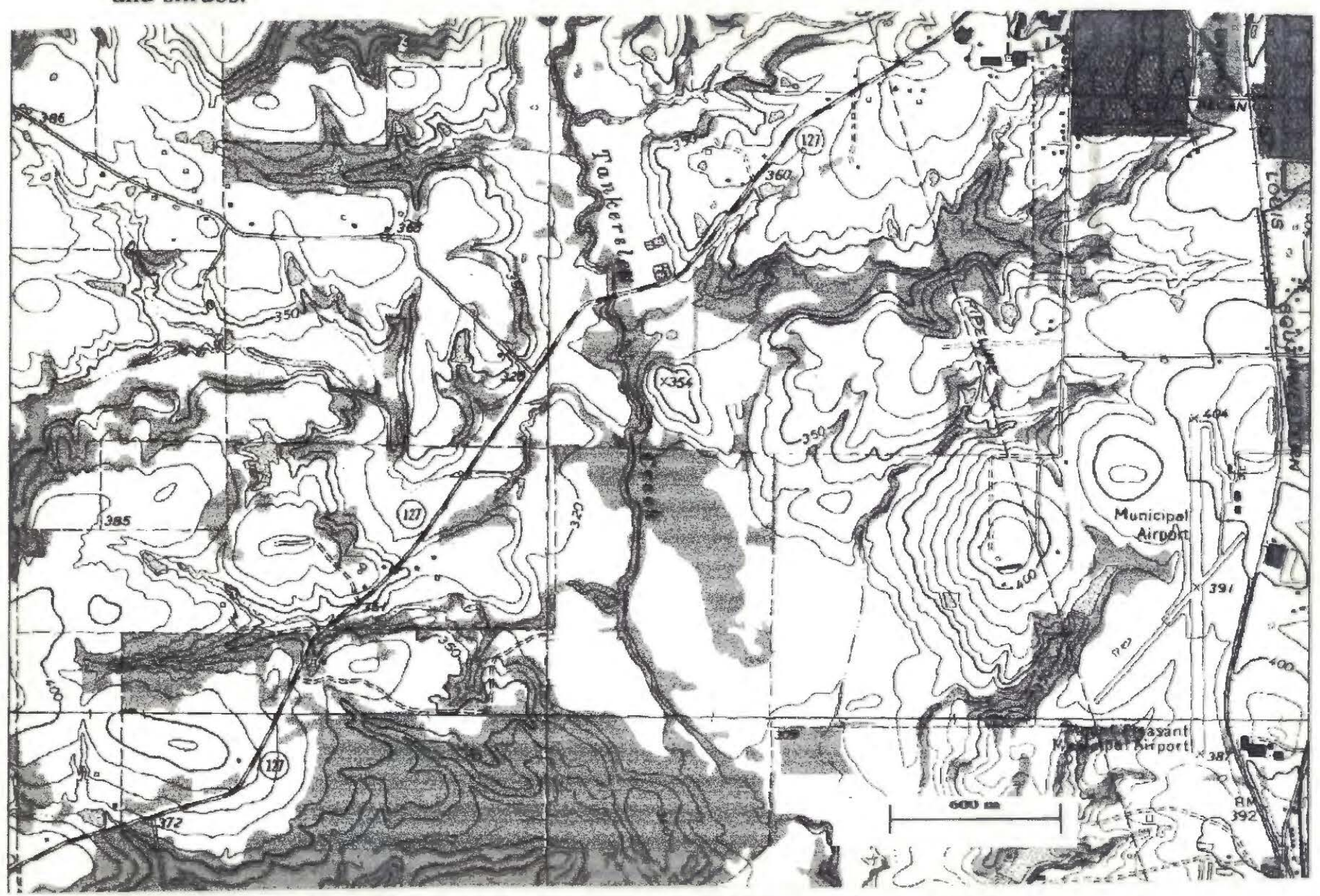

Figure 1. General location of the Crabb site and the Tankersley Creek valley, southwest of Mount Pleasant, Texas. 
The Tankersley Creek valley is well-known for its archacological resources, particularly those of prehistoric Caddo age, and numerous prehistoric Caddo sites have been identified and recorded in the valley in the last 20 years (see Thurmond 1990; Perttula et al. 2002). The Crabb site is one of several dozen prehistoric Caddo sites known in the creek valley, and one where limited investigations over the last 10 years have recovered interesting archaeological information about an intensive Caddo settlement that was apparently occupied at least 600-700 years ago (see Nelson and Turner 1997:4), if not longer. Additional archacological work is planned at the Crabb site should time and money become available to conduct more work at this significant site, but we believe it is important for future Caddo archaeological researchers that we make available now the archaeological information that has been obtained to date from the site.

\section{DISCOVERY OF THE SITE AND WORK CONDUCTED THERE}

The Crabb site was discovered by Marty Crabb in the early $1990 \mathrm{~s}$, and he had found ceramic sherds, arrow points, and dart points on the surface along the crest of the upland remnant. When he excavated a shovel test (what we are calling ST 4) on the landform (Figure 2) in early 1993, he discovered three plain vessels that may have been from a prehistoric Caddo burial. We discuss the vessels in the next section of this article.

Bo Nelson returned to the site with Marty Crabb in May 1993, and excavated three additional shovel tests (ST 1-3) - about five meters apart-west and southwest from the test that had the three plain vessels. These indicated that there were well-preserved midden deposits (of undetermined extent) of prehistoric Caddo age on the site, to depths of ca. 50 $\mathrm{cm}$ bs, and the midden deposits contained high densities of plain and decorated pottery sherds, daub, lithic cores and debris, fire-cracked rock, animal bone, and mussel shell fragments. On the basis of the decorated pottery sherds recovered in the shovel testing-including numerous incised sherds-it seemed likely that the Crabb site was occupied in Early to Middle Caddo period times (Nelson and Turner 1997).

Other than documenting the vessels recovered by Marty Crabb, that is where things stood concerning our understanding of the prehistoric archaeology of the Crabb site until we had an opportunity in April 2002 to return to the site to conduct additional shovel testing. The shovel testing was done to better establish the extent of the midden deposits, obtain soil samples and charred plant remains for purposes of dating the archaeological deposits, and try to clarify with minimal damage to these archaeological deposits the possible context of the three vessels found by Marty Crabb nine years earlier.

Four shovel tests (ST 5-8) were excavated at the Crabb site in 2002, and each turned out to be in the midden deposits (see Figure 2). From what we know now, the midden deposits cover at least a $21 \times 15 \mathrm{~m}$ area, over 300 square meters. This is a substantial-sized midden on a Caddo settlement, and suggests that there is a good-sized residential component present at the Crabb site around the midden deposits. The midden, a very dark brown to very dark grayish-brown sandy loam (Zone 1), is at least $30-43 \mathrm{~cm}$ in thickness, beginning at the modern ground surface, with the thickest deposits in ST 6 (sce Figure 2). In one shovel test (ST 8), there were patches of a clay fill in and overlying the midden deposits, which suggested there may have been a prehistoric pit in the area. The midden overlay a yellowish-brown sandy loam E-horizon (Zone 2) and a strong brown sandy clay (Zone 3) B-horizon. In ST 5-7, the Zone 3 sandy clay was exposed at 40 to 50 $\mathrm{cm}$ bs, but in ST 8, the B-horizon was not reached until $85 \mathrm{~cm}$ bs. 


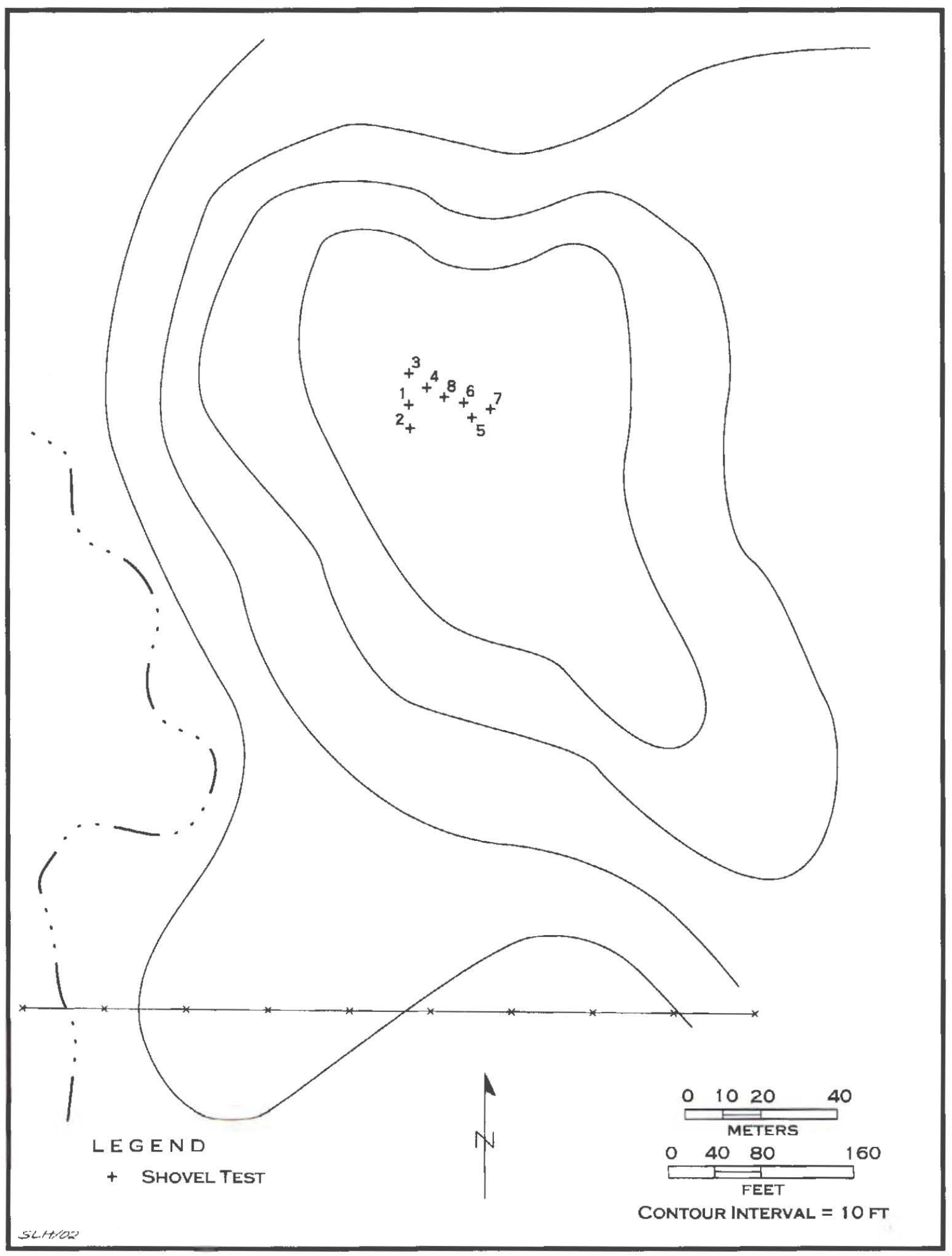

Figure 2. Shovel tests 1-8 at the Crabb site (41TT650). 
At the same time as the 2002 shovel testing at the Crabb site, we recorded another prehistoric Caddo site - the Baggerman site (41TT861) - on the southeastern tip of the remnant upland landform (Perttula et al. 2002:78-81). This site, with a high frequency of bone tempering in the pottery, the fairly thick vessel body walls, and the occurrence of several incised and punctated sherds, appears to be broadly contemporaneous with the Crabb site on the crest of the landform.

\section{THE VESSELS FOUND IN THE MIDDEN}

Three small and plain vessels were found in 1993 in ST 4 by Marty Crabb. Vessel 1 (Figure 3a-b) is a short-rimmed carinated bowl with a flat lip and a flat bottom. It is about $5.2 \mathrm{~cm}$ in height, and has an orifice diameter of $12.2 \mathrm{~cm}$.
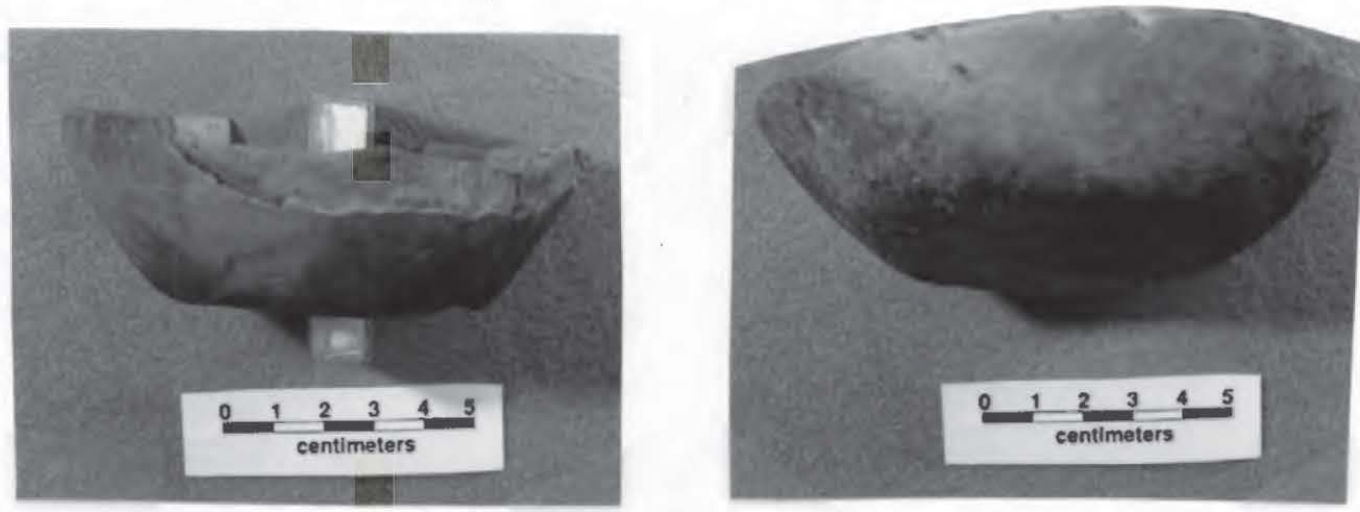

Figure 3. Vessel 1 from the Crabb site: $a$, side view; b, top to bottom view of the vessel.

Vessel 2 is a simple bowl with a flat lip and a flat, circular base (Figure 4a-b). There are fire clouds on its exterior surface around the base and lower vessel body (see Figure 4b). The bowls orifice diameter is $10.9 \mathrm{~cm}$, and it only stands about $4 \mathrm{~cm}$ in height.
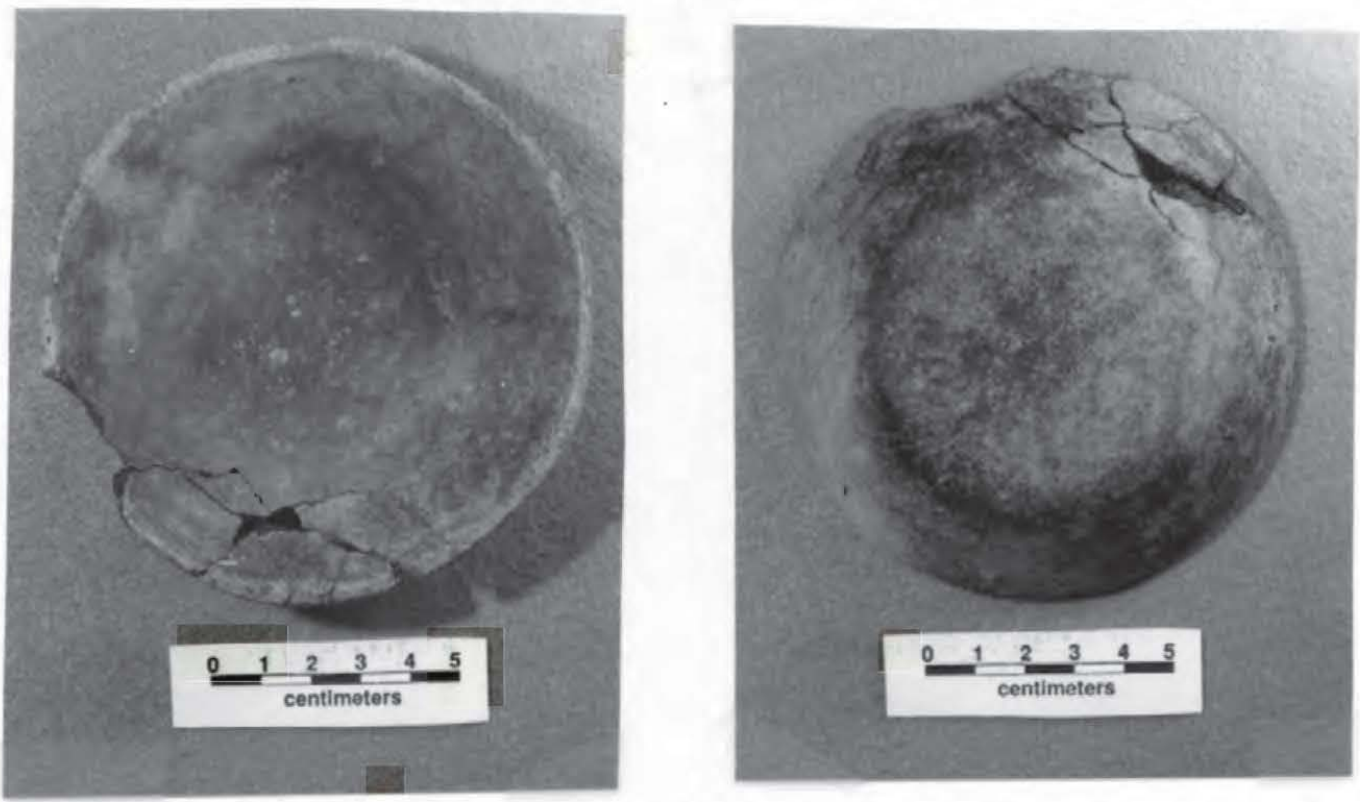

Figure 4. Vessel 2 from the Crabb site: a, looking at the vessel interior; vessel exterior, including the base. 
Vessel 3 is also a simple undecorated bowl with a flat lip; it probably had a flat base, although the base is mostly missing (Figure 5a-b). There are fire clouds on both interior and exterior vessel surfaces, primarily around the base and the lower part of the bowl. This vessel has a $10.2 \mathrm{~cm}$ orifice diameter, and stands about $4 \mathrm{~cm}$ in height.
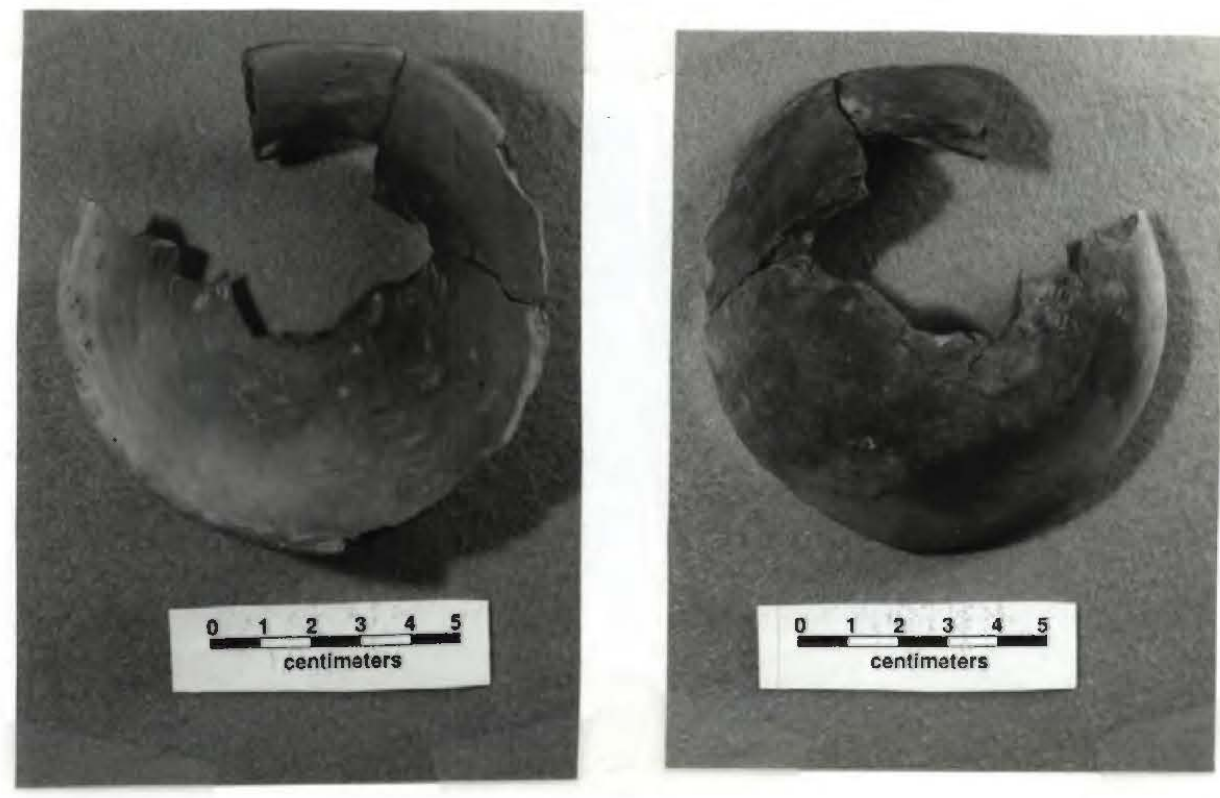

Figure 5. Vessel 3 from the Crabb site: a, vessel interior; b, vessel exterior.

If these three vessels are from a prehistoric Caddo burial - and that seems likely, even in the absence of any preserved human remains, because whole vessels are rarely found on Caddo sites in other than burial context - there small size suggests they may have been funerary objects for a Caddo child or young adult. The small bowls and carinated bowls would probably have held foods or other items needed by the deceased in their journey to the after-life.

The fact that the vessels are plain may have chronological significance, since plain vessels are rarely found in burials dating after ca. A.D. 1200-1400 in this part of the East Texas Pineywoods. We will return to the question of the age of the Caddo occupation at the Crabb site later in this article.

\section{ARTIFACTS FROM THE MIDDEN DEPOSITS}

A wide variety of prehistoric artifacts has been recovered at the Crabb site (Table 1) in the shovel testing. This includes lithic debris, cores, and several fire-cracked rocks from use in hearths and cooking pits, but many plain and decorated pottery sherds from utility ware and fine ware vessels, as well as daub and burned clay. Several of the shovel tests in the midden recovered animal bones and charred plant remains, along with fragments of freshwater mussel shells. The density of artifacts in the shovel testing is also impressive: almost 45 artifacts per each shovel test, which is about 360 artifacts per square meter. Three shovel tests (ST 1, ST 5, and ST 6) each had more than 60 artifacts (see Table 1), more than 480 artifacts per square meter. Clearly, the midden at the Crabb site is the product of intensive trash disposal from a prehistoric Caddo domestic occupation of some permanence. 
Table 1. Artifacts recovered from the Crabb site (41TT650).

\begin{tabular}{|c|c|c|c|c|c|c|c|c|c|}
\hline $\begin{array}{l}\text { Artifact } \\
\text { Type }\end{array}$ & ST 1 & ST 2 & ST 3 & ST 4 & ST 5 & ST 6 & ST 7 & ST 8 & $\mathrm{~N}$ \\
\hline Lithic Core & 1 & - & 1 & - & - & - & - & - & 2 \\
\hline Lithic Debris & 6 & 1 & - & - & 13 & 7 & 9 & 6 & 42 \\
\hline \multicolumn{10}{|l|}{ Fire-cracked } \\
\hline Rock & 7 & 1 & 1 & - & - & - & - & 2 & 11 \\
\hline Plain Rim & 1 & 1 & - & - & 1 & - & - & 1 & 4 \\
\hline Plain Body & 34 & 3 & 6 & - & 30 & 21 & 34 & 15 & 143 \\
\hline Plain base & 3 & - & 1 & - & - & - & - & - & 4 \\
\hline Decorated Rim & 3 & 1 & - & - & - & - & 2 & - & 6 \\
\hline DecoratedBody & 12 & 2 & 3 & - & 5 & - & 5 & 3 & 30 \\
\hline Daub & 1 & - & - & - & - & - & - & - & 1 \\
\hline Burned Clay & - & - & - & - & 12 & 2 & 8 & 1 & 23 \\
\hline Animal bone & 26 & - & 5 & - & 3 & - & 1 & 2 & 37 \\
\hline Mussel shell & - & - & 4 & - & - & - & - & - & 4 \\
\hline \multicolumn{10}{|l|}{ Charred plant } \\
\hline Remains & - & - & - & - & 4 & 2 & 1 & - & 7 \\
\hline Totals & 94 & 9 & 21 & $3^{*}$ & 68 & 32 & 60 & 30 & 314 \\
\hline
\end{tabular}

*the three whole vessels are not included in the artifact totals

More than $91 \%$ of the artifacts found in shovel testing come from shallow depths, namely $0-40 \mathrm{~cm}$, with the highest densities found between $0-20 \mathrm{~cm}$ bs. Less than $2 \%$ are from depths greater than $60 \mathrm{~cm}$ bs, and these probably either originated at higher depths and were moved deeper by bioturbation as well as the movements of gophers in the sandy sediments, or they represent artifacts that may have come from undetected pits and features below the midden deposits.

The lithic debris and cores are from local raw materials, principally quartzite and petrified wood. One single platform flake core (in ST 1) was on a dull reddish-gray chert, and the core fragment in ST 3 was on a gray chert. We suspect that these cherts were also available in local stream and upland gravels, though they would not have been as common a raw material as the coarser and harder to knap quartzites and petrified wood.

Fire-cracked rocks of quartzite are relatively common in the midden deposits, especially in ST 1 and ST 8 (see Table 1). The presence of fire-cracked rock suggests that the prehistoric Caddo living at the Crabb site continued to use rock hearths and ovens for cooking and food processing activities at the same time as they were employing ceramics for cooking purposes. Perhaps hot rock cooking was preferred for use occasionally to cook and roast certain foods that were not deemed suitable for cooking in ceramic cooking pots.

Sherds from ceramic vessels are very abundant in the Crabb site midden, and they account for almost $60 \%$ of the entire artifact collection recovered in the shovel testing (see Table 1). The density of sherds is about 190 sherds per square meter, based on the shovel testing, which translates to about 57,000 vessel sherds in the 300 square meter Crabb site midden deposits. 
The 187 sherds include 151 plain rim, body, and base sherds as well as 36 decorated sherds (see Table 1). This is a plain to decorated sherd ratio (PDR) of 4.19. The majority of the sherds are tempered solely with grog or crushed sherds (65\%), and $23 \%$ of the sherds also came from vessels that had been tempered with both grog and bone. Two sherds were tempered with either grog and crushed pieces of hematite or grog, bone, and hematite pieces, while a third sherd was tempered solely with burned and crushed bone.

A small amount of the vessel sherds (9\%) are from vessels manufactured with a naturally sandy clay. The remainder have a clay paste, and we suspect that the majority (if not all) of the sherds are from vessels made with a local clay (see below).

The 36 decorated rim and body sherds are represented by both utility wares $(67 \%)$ and fine wares (33\%) (Table 2). The utility wares are from vessels intended for use as cooking pots and for every-day and heavy-duty activities. The fine wares, on the other hand, are from well-made, burnished, engraved, and red-slipped carinated bowls and bowls, and were probably used less often on a regular basis, probably to serve foods and liquids in family ceremonies and group gatherings, somewhat like the "fine china" in our grandmother's and parents homes today.

\section{Table 2. Decorative elements represented in the Crabb site decorated sherds.}

\section{Utility Wares}

Parallel incised lines, body $(n=7)$

Opposed incised lines, body $(n=3)$

Diagonal incised lines, $\operatorname{rim}(n=1)$ and body $(n=1)$

Horizontal and diagonal incised lines, body $(n=1)$

Triangular incised el., body $(n=1)$

Single incised line, body $(n=1)$

Incised-tool punctated zones, $\operatorname{rim}(\mathrm{n}=1)$

Single Incised line-tool punctated rows, body $(n=1)$

Incised-zoned fingernail punctated rows, body $(n=2)$

Tool punctated rows, body $(\mathrm{n}=1)$

Fingernail punctated rows, body $(n=4)$

\section{Fine Wares}

Diagonal engraved lines, $\operatorname{rim}(\mathrm{n}=2)$

Horizontal engraved lines, rim $(n=1)$

Opposed engraved lines/red slipped, $\operatorname{rim}(\mathrm{n}=1)$

Curvilinear engraved lines $(\mathrm{n}=2)$

Parallel engraved lines, body $(n=2)$

Single engraved line, body $(n=3)$

Exterior red-slipped, body $(n=1)$

The utility wares are dominated by incised $(n=15)$, incised-punctated $(n=4)$, and fingernail punctated $(n=4)$ sherds, with one sherd with rows of tool punctations on it (see Table 2). Notable by their absence are brushed body and rim sherds. 
The principal elements are simple sets of parallel incised lines (probably horizontal in orientation, but not determinable on the sherds), or sets of diagonal, opposed, or horizontal and diagonal lines. These incised lines may have been on both the rim and/or body of the utility ware vessels, but the only incised rim has diagonal incised lines, and this may be from a Dunkin Incised vessel. One body sherd has parts of several triangular incised motifs. Among the incised-punctated sherds, the decorative elements include straight sets of incised lines creating triangular zones filled with either tool or fingernail punctations. The fingernail or tool punctated sherds have at least one row of punctations on them.

Among the fine wares, one body sherd has a hematite-rich red clay slip on its exterior surface; the other 11 fine ware sherds have engraved decorations. A distinctive sherd at the Crabb site-a rim - has an exterior red slip into which an opposed engraved element was etched after it was fired. There are no triangular excised areas on the sherd, which otherwise resembles both Holly Fine Engraved and Sanders Engraved vessels from other sites in East Texas.

Two rim sherds from carinated bowls have diagonal engraved lines, and two bottle sherds have sets of curvilinear engraved lines. Other decorative elements include simple sets of parallel or horizontal engraved lines, probably decorating the rim of carinated bowls and simple bowls.

Three sherds from the Crabb site were submitted for instrumental neutron activation analysis (INAA) to try to chemically characterize the kinds of ceramics found on prehistoric Caddo sites in the Big Cypress Creek drainage, as well as to determine if they came from vessels that had been manufactured locally. The three sherds-including a plain body sherd, a tool punctated sherd, and an incised-punctated sherd-were determined to belong to the Titus chemical group (Descantes et al. 2003: Table 5), one of 12 different chemical groups represented in the INAA database from northeastern Texas and northwestern Louisiana. The Titus chemical group is principally found in vessel sherds from sites in the Big Cypress Creek and Sabine River drainage basins of northeastern Texas and northwestern Louisiana (see Perttula 2002: Figure 5.2), and we conclude that the Crabb site vessel sherds were very likely to have been manufactured with local clays.

We also recovered one piece of daub and 23 pieces $(9.2 \mathrm{~g})$ of burned clay in the midden. Such pieces are probably from remnants of a burned structure(s) on the site that had been thatch and clay-covered. All of the burned clay pieces came from $0-40 \mathrm{~cm}$ bs. Debris from the burned structure may have been gathered up and tossed on the midden during site clean-up activities. The structure or structures may be only a few meters away from the midden itself.

In an attempt to establish the age of the midden deposits at the Crabb site, we submitted five samples of sediments (about $200 \mathrm{~g}$ each) from Zone 1 and Zone 2 deposits in ST 7 for Oxidizable Carbon Ratio (OCR) dating (see Frink 1994). The dates obtained from the Zone 1 midden range between AD 1563-1738, while the Zone 2 E-horizon sediments have OCR dates that range from AD 1189 to AD 1396 (Table 3, see also Appendix 1). Two of the dates, one each from Zone 1 and Zone 2 , are on pedogenic markers: AD 1362-1396 (Zone 2) and AD 1657-1673 (Zone 1). These dated pedogenic markers probably represent periods of pedogenic stability in the sediment horizons (i.e., and post date the actual prehistoric occupation), but neither of them appear to be relevant to establishing the age of the prehistoric Caddo occupation at the Crabb site. 
Table 3. OCR dates from the Crabb site midden, ST 7.

\begin{tabular}{llll}
\hline Depth & Sediment Zone & Pedogenic Marker & Years (A.D.) \\
\hline $8-10 \mathrm{~cm}$ & Zone 1 midden & - & $1726-1738$ \\
$18-20 \mathrm{~cm}$ & Zone 1 midden & Yes & $1657-1673$ \\
$28-30 \mathrm{~cm}$ & Zone 1 midden & - & $1563-1585$ \\
$38-40 \mathrm{~cm}$ & Zone 2 E-horizon & Yes & $1362-1396$ \\
$48-50 \mathrm{~cm}$ & Zone 2 E-horizon & - & $1189-1233$ \\
\hline
\end{tabular}

The OCR dates from Zone 2 come closest to meeting our expectations (based primarily on the ceramic sherds) of the actual age of the Caddo occupation, but unfortunately they are from Zone 2, below the principal cultural-bearing sediments at the site. The Zone 1 OCR dates would be suitable if the Crabb site was occupied during the Late Caddo Titus phase - which we know dates from ca. A.D. 1430-1680) - but there is absolutely no evidence in the recovered artifacts to suggest that the site was occupied at that time.

When we turn to a closer examination of the plain and decorated sherds from the Crabb site, we can offer some suggestions about the possible age of the prehistoric Caddo component. First, the plain to decorated sherd ratio (P/DR) here is 4.19, and previous analyses of Caddo ceramic assemblages suggests that changes in the PDR have chronological implications. Specifically, sites with a P/DR over 3.00 appear to primarily date before A.D. 1200, while those sites with a P/DR between 1.30-2.65 date around A.D. 1200 - 1400. Even lower P/DR (0.30-1.30) have been documented on sites in the region that date to Late Caddo times. Simply on the basis of the P/DR at the Crabb site of 4.19, it seems likely that the site was occupied before A.D. 1200, perhaps even before A.D. 1100 .

Sites such as Griffin Mound (Nelson et al. 1996) and New Hope (41FK 107, Nelson and Perttula 2003), as well as others in the Big Cypress Creek drainage, with P/DR between 3.00 and 5.70 have no brushed sherds among the decorated sherds. One calibrated radiocarbon date from the Griffin Mound site (41UR142) ranges from AD 1 168-1286 (Nelson et al. 1996). Such is also the case at the Crabb site, and in fact, the use of brushing as a decoration (mainly on the body of utility ware vessels) tends to dominate Middle Caddo (ca. A.D. 1200-1400) and particularly Late Caddo (ca. A.D. 1400-1680) sites. For example, at $41 \mathrm{CP} 408$, radiocarbon-dated to AD 1280-1400), $12.5 \%$ of the sherds have brushing; the P/DR here is 1.93 (Perttula 2003). At 4ITT828, with OCR dates that range from AD 143I-1461, 20\% of the sherds are brushed, and the P/DR is 2.20 (Perttula and Nelson 2002). At the later Frank Benson site (4ITT310), with OCR dates that range from A.D. 1411-1595, 45\% of the sherds are brushed, and the P/DR is only 1.10.

Considering the P/DR values of these various sites in the Big Cypress Creek basin, along with the frequency of brushed pottery at them, it is evident that the Crabb site falls in with the earlier set of sites, such as Griffin Mound and New Hope, rather than the postA.D. 1280 sites in the same general area. In the absence of radiocarbon dates from the Crabb site midden deposits to confirm these chronological patterns, nevertheless we suspect that the Crabb site was occupied and used by the Caddo before A.D. 1200, but certainly after ca. A.D. 1000. 


\section{FAUNAL REMAINS, by LeeAnna Schniebs}

A total of 31 faunal remains were recovered and analyzed from two of the first three shovel tests at the prehistoric Caddo Crabb site (41TT650) in Titus County, Texas (Appendix 2); a small amount of unidentifiable fauna was also recovered from ST 5-8 (see above). Total weight of the analyzed collection is $29.8 \mathrm{~g}$ (Table 4).

\section{Table 4. Taxonomic composition of faunal specimens from Crabb site} (41T'T650) shovel tests.

\begin{tabular}{|l|l|l|l|r|r|r|} 
& & & & & \\
Scientific Name & Common Name & NISP & MNI & of Site & Wt/g & \\
\hline Mammalia (large) & Ig. mammal & 26 & & 84 & 9.9 \\
\hline Cervidae & deer or elk (antler) & 1 & & 3 & 4.8 \\
\hline Artiodactyl (medium) & deer-size artiodactyl & 4 & 1 & 13 & 15.1 \\
\cline { 2 - 6 } & TOTAL & 31 & & 100 & 29.8 \\
\hline
\end{tabular}

Unidentifiable large mammal bones dominate the sample, but medium-sized artiodactyl and cervid (from antler) remains are also present at the Crabb site. These remains are likely those of deer (Odocoileus sp.), but a specific identification was not attempted because of the fragmentation of the animal bone. A minimum of one individual was present at the site, although two calcaneous fragments may be from two different individuals. One specimen was much smaller than the other, possibly from a younger animal.

Deer is the most common large game animal found in faunal assemblages from Caddo archaeological sites, and also one of the Caddo's main subsistence animals. However, the elements recovered (i.e., unidentifiable fragments, podial fragments, and long bone fragments, Table 5) are not high-yield meat items.

Table 5. Composition of faunal elements from Crabb site (41TT650) shovel tests.

\begin{tabular}{|c|c|c|c|c|c|}
\hline \multirow[t]{2}{*}{ Scientific Name } & Common Name & Element & & & \multirow[b]{2}{*}{ other } \\
\hline & & unidentifiable & long bone & podial & \\
\hline Mammalia (large) & Ig. mammal & 21 & 5 & & \\
\hline Cervidae & deer or elk (antler) & & & & ( \\
\hline \multirow{2}{*}{ Artiodactyl (medium) } & deer-size artiodactyl & & 1 & 3 & \\
\hline & TOTAL & 21 & 6 & 3 & 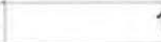 \\
\hline \multicolumn{6}{|l|}{ NOTE: } \\
\hline \multirow{2}{*}{\multicolumn{6}{|c|}{$\begin{array}{l}\text { "Long Bone" inc. a femur fragment as well as unidentifiable fragments. } \\
\text { "Podial" inc. two calcaneus fragments and one navicular cuboid fraament. }\end{array}$}} \\
\hline & \multicolumn{5}{|c|}{ "Podial" inc. two calcaneus fragments and one navicular cuboid fragment. } \\
\hline "Other" inc. one antle & fragment. & & & & \\
\hline
\end{tabular}

In general, the bone fragments from the site are in good condition, but exfoliation and abrasion were noted in the collection (Table 6). Fifteen of the specimens are burned (Table 7), almost $50 \%$, and this is probably a result of trash disposal in the Crabb site midden deposits. Shovel test 1 yielded 23 large-sized mammal and three medium-sized artiodactyl bones. Three large mammal bones, one medium-sized artiodactyl bone, and one antler fragment were recovered from ST 3 (Table 8). 
Table 6. Taphonomic patterns on faunal specimens from Crabb site (41TT650) shovel tests.

\begin{tabular}{|c|c|c|c|c|}
\hline \multirow[t]{2}{*}{ Scientific Name } & \multirow[t]{2}{*}{ Common Name } & \multicolumn{2}{|c|}{ Type of Taphonomy } & \\
\hline & & absent & exfoliation & abrasion and exfoliation \\
\hline Mammalia (large) & Ig. mammal & 13 & 13 & \\
\hline Cervidae & deer or elk (antler) & 1 & & \\
\hline Artiodactyl (medium) & deer-size artiodactyl & 2 & & 2 \\
\hline & TOTAL & 16 & 13 & 2 \\
\hline
\end{tabular}

Table 7. Summary of burning patterns on faunal specimens from the Crabb site (41TT650).

\begin{tabular}{|c|c|c|c|c|c|}
\hline \multirow[t]{2}{*}{ Scientific Name } & Common Name & Degree of $E$ & Burning & & \multirow[b]{2}{*}{ white } \\
\hline & & not burn & charred & black & \\
\hline Mammalia (large) & lg. mammal & 14 & & 3 & 9 \\
\hline Cervidae & deer or elk (antler) & & 1 & & \\
\hline \multirow[t]{2}{*}{ Artiodactyl (medium) } & deer-size artiodactyl & 2 & 2 & & \\
\hline & TOTAL & 16 & 3 & 3 & 9 \\
\hline
\end{tabular}

Table 8. Distribution of Crabb site (41TT650) faunal specimens.

\begin{tabular}{|l|l|r|r|}
\hline & & & \\
Scientific Name & Common Name & Shovel Test 1 & Shovel Test 3 \\
\hline Mammalia (large) & Ig. mammal & 23 & 3 \\
\hline Cervidae & deer or elk (antler) & 3 & 1 \\
\hline Artiodactyl (medium) & deer-size artiodactyl & 26 & 1 \\
\hline & TOTAL & 5 \\
\hline
\end{tabular}

The small faunal collection from the Crabb site (41TT650) gives further evidence to the fact that the prehistoric Caddo peoples supplemented their diet with large game, probably deer, utilizing the rich animal resources of East Texas. The sample from the Crabb site reveals the potential for further investigations here to provide additional information on prehistoric Caddo subsistence practices. 


\section{CONCLUDING COMMENTS}

The Crabb site (41TT650) appears to be a well-preserved and single component prehistoric Caddo occupation in the Pineywoods of East Texas. Our best guess at this time - in the absence of any radiocarbon dates from the midden - is that the site was occupied by the Caddo between ca. A.D. 1000-1200.

Early Caddo sites and components along Big Cypress Creek in the Lake Bob Sandlin area (just south of the Crabb site) are widely spaced across the lake area, but occur primarily along Big Cypress Creek and Brushy Creek. Components outside of the main stream valley can be found on Camp Branch and Stouts Creek, as well as the unnamed tributary on the north side of the valley near the Lake Bob Sandlin dam (Nelson and Perttula 2003: Figure 22). The confluence of Tankersley Creek with Big Cypress Creek is just below the Lake Bob Sandlin dam.

Archaeological evidence from Lake Bob Sandlin sites, and other sites investigated elsewhere in the Big Cypress Creek basin, indicate that many of the Early and Middle Caddoan components here represent permanent, year-round, settlements of horticultural peoples. The locations that they chose to permanently settle and build structures and other facilities at had to be situated in habitats where suitable sandy soils were nearby that could be worked with simple wood and bone digging tools, and that the land they built their homesteads and communities on had to be well-drained and elevated above the annual floods along Big Cypress Creek and its tributaries. They also had to be in areas where wood and grass was plentiful for house construction and refurbishing, as well as near fresh drinking water. The fact that the Early and Middle Caddoan settlements are not found in any notable spatial clusters within the lake area (except perhaps for one cluster of Early Caddo components along the edge of the Big Cypress Creek alluvial valley and west of its confluence with Camp Branch, see Nelson and Perttula 2003: Figure 22) suggests that the many resources that were needed by sedentary Caddo populations to successfully live in the Big Cypress Creek valley could best be exploited by dispersing the groups in a variety of settings.

This dispersed settlement arrangement would have helped lessen the competition for such resources, and not allow for the environmental degradation of suitable habitats by a single large community. It would also permit the Caddo peoples to take advantage of the diversity in habitats to exploit a number of them, thus insuring that the overall community could survive if there were economic difficulties or failures (i.e., local droughts, flooding, fires) in some habitats but not in most of the others.

The size of the Crabb site midden, and the density of artifacts contained in its deposits, strongly suggest that the Crabb site was a permanent and year-round settlement of Caddo peoples, perhaps several extended families or clusters of nuclear families. The Crabb site has considerable potential to provide new and important information on the character of an Early Caddo settlement in the Big Cypress Creek basin, and we hope that further archaeological work can be conducted there in the not-too-distant future.

\section{ACKNOWLEDGMENTS}

We thank Sandra Hannum for preparing the Figure 2 site map. We also appreciate the help of Mark Walters in the 2002 shovel testing at the Crabb site. 


\section{REFERENCES CITED}

Descantes, C., R. J. Speakman, and M. D. Glascock

2003 Letter Report to Timothy K. Perttula with enclosed figures and tables. University of Missouri Research Reactor, Columbia, September 3, 2003, 40 pp.

Frink, D. S.

1994 The Oxidizable Carbon Ratio (OCR): A Proposed Solution to some of the Problems Encountered with Radiocarbon Data. North American Archaeologist 15(1):17-29.

Nelson, B. and T. K. Perttula

2003 Archeological Survey along the Lake Bob Sandlin Shoreline, Camp, Franklin, and Titus Counties, Texas. Report of Investigations No. 46. Archeological \& Environmental Consultants, LLC, Austin.

Nelson, B. and M. Turner

1997 Middle Caddoan Sites in the Cypress Creek Drainage Basin. Journal of Northeast Texas Archaeology 10:1-11.

Nelson, B., M. Turner, and T. K. Perttula

1996 Archeological Investigations at the Griffin Mound Site: A Middle Caddoan Site in Upshur County, Texas. The Cache, Collected Papers on Texas Archeology: 3:4966. Office of the State Archeologist, Texas Historical Commission, Austin.

Perttula, T. K.

2002 Archaeological Evidence for the Long-Distance Exchange of Caddo Indian Ceramics in the Southern Plains, Midwest, and Southeastern United States. In Geochemical Evidence for Long-Distance Exchange, edited by M. D. Glascock, pp. 89-107. Bergin and Garvey, Westport, Connecticut.

2003 Prehistoric Caddo Ceramics from 41CP408 in the Proposed Leesburg Mine, Camp County, Texas. MS on file, PBS\&J, Inc., Austin.

Perttula, T. K. and B. Nelson

2002 Archeological Survey of Lake Bob Sandlin State Park, Titus County, Texas. Report of Investigations No. 48. Archeological and Environmental Consultants, Austin.

Perttula, T. K., B. Nelson, and T. C. Schultz

2002 Archeological Survey of the U.S. 271, Mount Pleasant Loop, Titus County, Texas, for the Texas Department of Transportation. Archeological \& Environmental Consultants, LLC, Austin.

Thurmond, J. P.

1990 Archeology of the Cypress Creek Drainage Basin, Northeastern Texas and Northwestern Louisiana. Studies in Archeology 5. Texas Archeological Research Laboratory, The University of Texas at Austin. 


\section{APPENDIX 1, OCR DATES}


Archaeology Gonsulting Team, Inc.

57 River Road - Suite 1020

Essex, Vermont 05452

(802) 879-2047

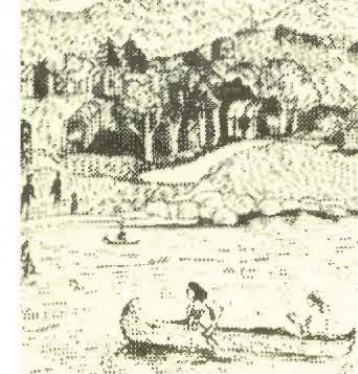

(5)

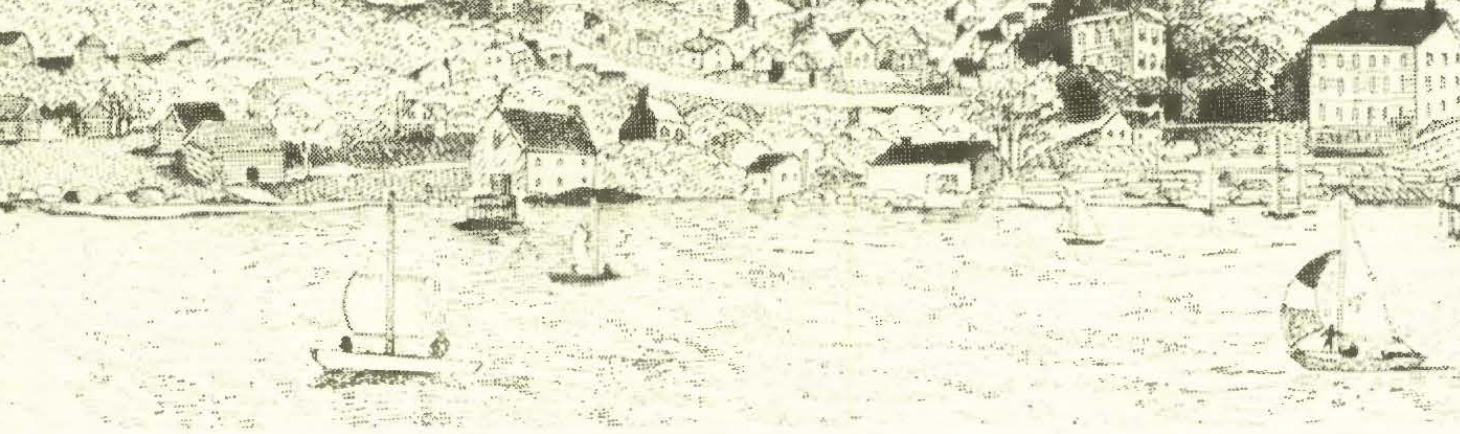

July 17,2002

Dr. Timothy Perttula

Archaeological \& Environmental Consultants

10101 Woodhaven Drive

Austin, TX 78753

Dear Dr. Perttula:

Thank you for sending us the additional soil samples from 41TT650 for OCR DATE analyses. These samples were received on May 22, 2002, in good condition.

Prior to our analyses, we screened the samples through a $2 \mathrm{~mm}$-meshed screen to remove any cultural material. The coarse fraction found in these samples is being returned to you for further study. The OCR DATE analyses were conducted in accordance with the procedures outlined in:

Frink, D.

1992 The Chemical Variability of Carbonized Organic Matter Through Time. Archaeology of Eastern North America, Vol. 20:67-79.

using the data format and formula as presented in:

Frink, D.

1994 The Oxidizable Carbon Ratio (OCR): A Proposed Solution to Some of the Problems Encountered with Radiocarbon Data. North American Archaeologist. Vol.15 (\#1). 
The results of the OCR analyses for your samples are presented on the separate computer printouts. The bottom line OCR $\mathrm{DATE}_{\mathrm{DT}}$ and the confidence interval have been rounded to the nearest year. Also, the expression of results has been adjusted to "years before present"- defined as 1950, to correspond with calibrated ${ }^{14} \mathrm{C}$ radiocarbon data. For example, your sample from $39 \mathrm{~cm}$ bs (ACT \#6026) should read OCR DATE: $^{571} \pm 17$ YBP. Further rounding may be prudent (e.g., $570+/-20$ YBP).

Please note, that in addition to the individual data printouts, we have provided data tables for the column. The highlighted data set represent significant pedologic events of stability. These might be natural, environmental, cultural, or a combination of any of these events. The intent to suggest contextual data within which your artifactual material may be interpreted.

I hope that the OCR sites. If you have further questions on the OCR procedure, please don't hesitate to give us a call. To aid us in improving this dating technique, we would appreciate it if you would send us information on how the OCR DATE corresponds to other data classes for these samples.

Also please feel free to keep track of the OCR literature and data on our WEBSite:

http://members.aol.com/dsfrink/ocr/ocrpage.htm

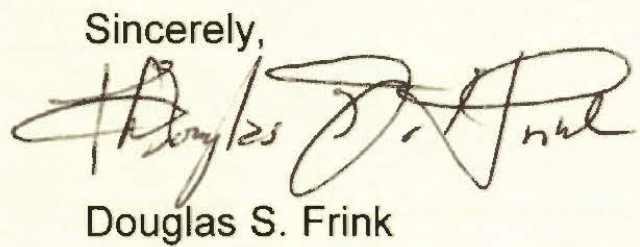


Calculated OCR DATE Report

\section{For Archeological \& Environmental C}

17-Jul-02

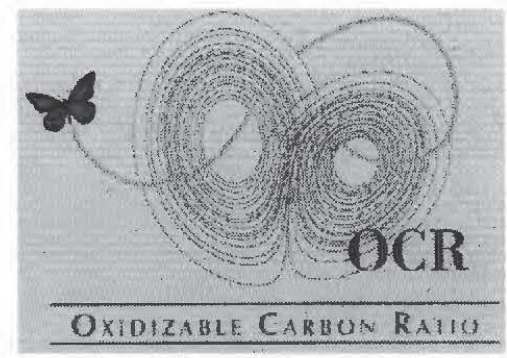

\begin{tabular}{|c|c|c|}
\hline Sample Id: & ACT \# 6023 & \\
\hline Site Id \#: & 41-TT-650 & \\
\hline Location: & Mt. Pleasant,Tx ST7 & \\
\hline Feature Type: & Cultural & \\
\hline Feature Designation: & & \\
\hline Sample Recieved: & $5 / 22 / 02$ & \\
\hline Calculated OCR DATE: & 218 & YBP(1950) \\
\hline
\end{tabular}

\begin{tabular}{|c|c|}
\hline Sample Id: & ACT \# 6024 \\
\hline Site Id \#: & 41-TT-650 \\
\hline Location: & Mt. Pleasant, Tx ST7 \\
\hline Feature Type: & Cultural \\
\hline Feature Designation: & \\
\hline Sample Recieved: & $5 / 22 / 02$ \\
\hline Calculated OCR DATE: & 285 \\
\hline
\end{tabular}

\begin{tabular}{|c|c|c|}
\hline Sample Id: & ACT \# 6025 & \\
\hline Site Id \#: & 41-TT-650 & \\
\hline Location: & Mt. Pleasant,Tx ST7 & \\
\hline Feature Type: & Cultural & \\
\hline Feature Designation: & & \\
\hline Sample Recieved: & $5 / 22 / 02$ & \\
\hline Calculated OCR DATE: & $376 \mid$ YBP $(1950)$ & $+1-11$ \\
\hline
\end{tabular}

\begin{tabular}{|c|c|c|}
\hline Sample Id: & ACT \# 6026 & \\
\hline Site Id \#: & 41-TT-650 & \\
\hline Location: & Mt. Pleasant, Tx ST7 & \\
\hline Feature Type: & Cultural & \\
\hline Feature Designation: & & \\
\hline Sample Recieved: & $5 / 22 / 02$ & \\
\hline Calculated OCR DATE: & 571 & YBP(1950) \\
\hline
\end{tabular}




\section{Calculated OCR DATE Report}

\section{For Archeological \& Environmental C}

17-Jul-02

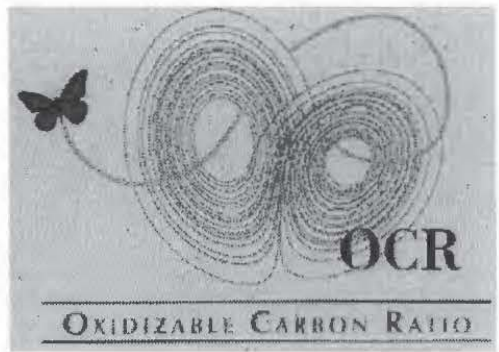

\begin{tabular}{|r|r|}
\hline Sample Id: & ACT\# 6027 \\
\hline Site Id \#: & $41-T T-650$ \\
\hline Location: & Mt. Pleasant, Tx ST7 \\
\hline Feature Type: & Cultural \\
\hline Feature Designation: & \\
\hline Sample Recieved: & $5 / 22 / 02$ \\
\hline Calculated OCR DATE: & 739 \\
\hline
\end{tabular}




\section{TT650}

\begin{tabular}{|c|c|c|c|c|c|c|c|c|c|c|c|c|c|c|}
\hline $\begin{array}{c}\text { Soil } \\
\text { Depth }\end{array}$ & $\mathrm{pH}$ & $\begin{array}{c}\% \\
\text { Organic } \\
\text { Carbon } \\
\text { (LOI) }\end{array}$ & $\begin{array}{l}\text { Ocr } \\
\text { Date }\end{array}$ & $\begin{array}{l}\text { Very } \\
\text { Coarse }\end{array}$ & Coarse & Medium & Fine & $\begin{array}{l}\text { Very } \\
\text { Fine }\end{array}$ & $\begin{array}{c}\text { Coarse } \\
\text { Silt }\end{array}$ & $\begin{array}{l}\text { Fine } \\
\text { silt }\end{array}$ & $\begin{array}{l}\text { Sample } \\
\text { Id }\end{array}$ & \begin{tabular}{c|}
$\%$ \\
$\begin{array}{c}\text { Oxidizable } \\
\text { Carbon } \\
\text { (WB }\end{array}$
\end{tabular} & $\begin{array}{l}\text { OCR } \\
\text { Ratio }\end{array}$ & Mn \\
\hline 9 & 4.6 & 1.979 & 218 & .454 & .603 & .904 & 3.781 & 28.715 & 36.378 & 29.166 & 6023 & 0.78 & 2.54 & 15.68 \\
\hline 19 & 4.7 & 1.764 & 285 & 1.453 & 1.920 & 1.028 & 3.842 & 28.217 & 33.129 & 30.411 & 6024 & 0.64 & 276 & 28.18 \\
\hline 29 & 5.2 & 1.091 & 376 & .485 & .610 & .980 & 2.929 & 28.880 & 36.128 & 29.987 & 6025 & 0.415 & 2.63 & 13.86 \\
\hline 39 & 5.2 & 0.701 & 571 & 526 & 1.156 & 3.11 & 3.206 & 25.227 & 35.937 & 30.840 & 6026 & 0.19 & 3.69 & 10.71 \\
\hline 49 & 5.3 & 1.317 & 739 & 276 & .080 & 614 & 3.081 & 28.315 & 36.237 & 31.397 & 6027 & 0.30 & 4.39 & 9.54 \\
\hline
\end{tabular}




\section{APPENDIX 2, FAUNAL INVENTORY}


41TT650

\begin{tabular}{|c|c|c|c|c|c|c|c|c|c|c|c|}
\hline Provenience & Qty & Taxon & Elem/Por & Side & Age & Weather & Burn & Gnaw & Mod & Wt/g & Comments \\
\hline Shov Test 1 & 2 & Ig mam & I.b.frag & & & exfol & not & carn & & 3 & \\
\hline Shov Test 1 & 11 & lg mam & unid & & & exfol & not & & & 1.2 & \\
\hline Shov Test 1 & 1 & Ig mam & unid & & & none & blk & & & 1.7 & \\
\hline Shov Test 1 & 8 & lg mam & unid & & & none & wh & & & 1 & \\
\hline Shov Test 1 & 1 & Ig mam & unid & & & none & not & carn & & 0.8 & \\
\hline Shov Test 1 & 1 & med art & calc frg & $R$ & & none & char & & & 4.8 & \\
\hline Shov Test 1 & 1 & med art & fem dist frg & & & abrade,exf & finot & & & 4.1 & \\
\hline Shov Test 1 & 1 & med art & nav cub frg & & & abrade,exf & finot & & & 2.5 & \\
\hline Shov Test 3 & 1 & cervid & antler frg & & & none & char & & & 4.8 & \\
\hline Shov Test 3 & & Ig mam & I.b.frag & & & none & blk & & & 1.2 & \\
\hline Shov Test 3 & & Ig mam & I.b.frag & & & none & wh & & & 1 & \\
\hline Shov Test 3 & & med art & calc platfor & & & none & char & & & 3.7 & Ig indiv \\
\hline
\end{tabular}

